\title{
Clinico-epidemiological profile of early cases of Covid-19 in state of Haryana,
} India

\author{
Vinod Chayal', Rohtas K. Yadav ${ }^{2}$, Ramesh Verma ${ }^{3}$, Meenakshi Kalhan ${ }^{4}$, Anuradha Nadda ${ }^{5}$, Shweta \\ Goswami $^{6}$, Rohit Dhaka ${ }^{7}$, Ginni Agrawal ${ }^{8}$, Gopal Kumar ${ }^{9}$, Aman Sachdewa ${ }^{10}$, Vidya Sagar ${ }^{11}$
}

${ }^{1}$ Associate Professor, Community Medicine, Pandit Bhagwat Dayal Sharma Post Graduate Institute of Medical Sciences, Rohtak; ${ }^{2}$ Director, Pandit Bhagwat Dayal Sharma Post Graduate Institute of Medical Sciences, Rohtak; ${ }^{3}$ Professor, Community Medicine Pandit Bhagwat Dayal Sharma Post Graduate Institute of Medical Sciences, Rohtak; ${ }^{4}$ Professor, Community Medicine Pandit Bhagwat Dayal Sharma Post Graduate Institute of Medical Sciences, Rohtak; ${ }^{5}$ Assistant Professor, Community Medicine, Dr. BR Ambedkar State Institute of Medical Sciences, Mohali; ${ }^{6}$ Assistant Professor, Community Medicine, ESIC Medical College and Hospital Faridabad; ${ }^{7}$ Senior Resident, Community Medicine ESIC Medical College and Hospital Faridabad; ${ }^{8}$ Senior Resident, Community

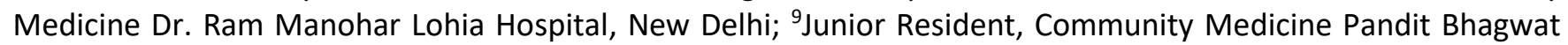
Dayal Sharma Post Graduate Institute of Medical Sciences, Rohtak; ${ }^{10}$ Junior Resident, Community Medicine Pandit Bhagwat Dayal Sharma Post Graduate Institute of Medical Sciences, Rohtak; ${ }^{11}$ Junior Resident, Community Medicine Pandit Bhagwat Dayal Sharma Post Graduate Institute of Medical Sciences, Rohtak

\begin{tabular}{|c|c|c|c|c|c|c|c|c|}
\hline Abstract & Introduction & Methodology & Results & Conclusion & References & Citation & \multicolumn{2}{|c|}{ Tables / Figures } \\
\hline \multicolumn{9}{|c|}{ Corresponding Author } \\
\hline \multicolumn{8}{|c|}{$\begin{array}{l}\text { Dr. Vinod Chayal, Dept. Of Community Medicine, Post Graduate Institute of Medical Sciences, } \\
\text { Medical Rd, Rohtak, Haryana } 124001 \\
\text { E Mail ID: } \underline{\text { drvinodchayal@gmail.com }}\end{array}$} & 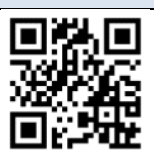 \\
\hline
\end{tabular}

\section{Citation}

Chayal V, Yadav RK, Verma R, Kalhan M, Nadda A, Goswami S, Dhaka R, Agrawal G, Kumar G, Sachdewa A, Sagar V. Clinico-epidemiological profile of early cases of Covid-19 in state of Haryana, India. Indian J Comm Health. 2021;33(1):97-102. https://doi.org/10.47203/IJCH.2021.v33i01.013

Source of Funding: Nil Conflict of Interest: None declared

\section{Article Cycle}

Received: 20/02/2021; Revision: 01/03/2021; Accepted: 05/03/2021; Published: 31/03/2021

This work is licensed under a Creative Commons Attribution 4.0 International License.

\section{Abstract}

Background: Covid -19 disease is caused by novel coronavirus known as SARS CoV 2. Coronaviruses are known to cause disease in humans which can be a common cold or a serious pneumonia. SARS Cov 2 is a new variant of coronavirus which was never reported in humans before detection of cluster of cases of pneumonia in Wuhan on 31st December, 2019.Objective: The study was conducted with the objective to find out clinico- epidemiological profiles of early Covid-19 patients in state of Haryana, India and to find out knowledge about covid appropriate behaviors among covid 19 patients. Methods: All the covid-19 cases in the five districts of Haryana were enumerated from March 2020 to May 2020. These Covid-19 cases were contacted telephonically and those who gave their consent to participate in the study were asked to fill interview schedule. Observations: There were 356 covid cases reported in five districts attached to PGIMS, Rohtak. Out of total,254 subjects participated in the study, there were $60.6 \%$ males and $39.4 \%$ females who participated in the study. Blood groups of all the participants were also enquired and it was observed that $B+v e$ was most common (19.7\%) blood group followed by $A+v e$ (16.5\%) and $O+v e(15.7 \%)$. Conclusion: It can be concluded by the study that majority of the subjects were males, overweight and blood group A \& B were the most common blood groups. It was observed that $75.2 \%$ participants were aware about the use of mask, social distancing, hand hygiene and cough etiquettes. 


\section{Keywords}

Epidemiological profile; Early cases; Covid-19 patients; Haryana.

\section{Introduction}

Covid -19 disease is caused by novel coronavirus known as SARS CoV 2. Coronaviruses are known to cause disease in humans which can be a common cold or a serious pneumonia. Corona virus derives its name from its crown like appearance when seen through electron microscope. (1) SARS CoV 2 is a new variant of coronavirus belonging to Beta coronavirus genus, which was never reported in humans before detection of cluster of cases of pneumonia in Wuhan on 31st December 2019. This virus rapidly spread to other parts of the world and on 11th March 2020 WHO declared it a pandemic. SARS CoV 2 is a single stranded RNA virus and causes flu like symptoms, mainly affecting lower respiratory tract as reported in various studies. $(2,3,4)$ Most common symptoms of Covid-19 disease are fever, dry cough and fatigue. Other symptoms are rhinitis, shortness of breath, conjunctivitis, sore throat, loss of taste $\&$ smell, body ache and diarrhea. (5) Usha $\mathrm{G}$ et al (6) depicted that fever and cough were the most common symptoms followed by sore throat, headache and breathlessness. Covid 19 has spread to all age groups but as observed by Kaiyuan Sun et al (7) it was more common in patients of age group 45 years and above. Only in $3 \%$ cases it was reported in subject less than 15 years of age. In the same study male preponderance was pointed out with $55 \%$ male cases reported. The mode of spread of SARS CoV 2 is from person to person either through direct inhalation of droplets or through fomites. (8) The incubation period of virus ranges from 1 to 14 days and patients can be symptomatic or asymptomatic. Symptomatic patients can transmit infection more effectively to the contacts but transmission through asymptomatic patients cannot be denied. $(9,10)$ Large majority of these patients are asymptomatic but as the transmission rate is high and as it is novel virus so case load of symptomatic and patients requiring admission is high. Considering the unpredictability of SARS CoV 2 in the manner it affects individual, this study is an attempt to throw some light on clinico-epidemiological profile of early Covid-19 patients.

\section{Aims \& Objectives}

1. The study was conducted with the objective to find out clinico- epidemiological profiles of early Covid-19 patients in state of Haryana, India.
2. To find out knowledge about covid appropriate behaviors among covid 19 patients in state of Haryana.

\section{Material \& Methods}

Study Setting and Design: There are 22 districts in Haryana, out of which five districts (Rohtak, Jhajjar, Bhiwani, Gurugram \& Charkhi Dadri) are attached to Pt. B. D. Sharma PGIMS, Rohtak for providing support through Rapid Response Teams for monitoring of Covid disease. The Rapid response teams consisted of one faculty member, one senior resident and two post-graduate students from Department of Community Medicine, Pt. Bhagwat Dayal Sharma Post Graduate Institute of Medical Sciences, Rohtak. A descriptive cross-sectional study was conducted in these five districts.

Study Population and sampling technique: Universal sampling was followed where all the confirmed cases from March 2020 to May 2020 of these five districts were enrolled in the study. There were 356 total cases reported in these three months. Study tools and technique: A semi-structured and pre-tested interview schedule was used for interviewing the study subjects. Patients were contacted telephonically. The interview schedule contained information on general demographic characteristics, co-morbid conditions of cases and contacts, symptoms, preventive measures.

Data Collection: All the confirmed cases from March 2020 to June 2020 were contacted telephonically. Out of 356 cases, 254 gave their consent to participate in the study. During telephonic conversation, initial some time was spent with the subject to build rapport asking him/her about general wellbeing. Patients who gave verbal consent for participation, were interviewed using a predefined, pretested semi-structured interview schedule. The queries of the study subjects were answered after the interview schedule and any myths or misconceptions of study subjects were removed.

Consent: An informed verbal consent/ascent was obtained from the subjects enrolled in the study. The subjects were explained about the proforma and whoever not interested was not enrolled in the study.

Ethical Considerations: Institutional Ethics Committee approval was obtained. Confidentiality of 
the data was religiously maintained by the investigator.

Data analysis: The study data was analyzed by applying percentages and proportions for different parameters. The SPSS version 20 was used to analyze the data. The analyzed data was appropriately interpreted for drawing conclusions.

\section{Results}

As shown in (Table 1), there were 356 covid cases reported in five districts attached to PGIMS, Rohtak, Haryana in month of March-May 2020. All of these covid cases were telephonically contacted, out of these only 254 study subjects gave consent to participate in the study, rest either didn't pick up the call or refused to participate in the study. Out of 254 study subjects, $60.6 \%$ were males and $39.4 \%$ females. Most (95.3\%) of the study subjects were educated and only $4.7 \%$ were illiterate. Among study participants $40.6 \%$ were graduate and $20 \%$ were educated till senior secondary. There $6.3 \%$ subjects educated till primary, $7.1 \%$ till middle and $9.4 \%$ till matriculate. There were $9.4 \%$ who did their postgraduation too. Body mass Index was also calculated and as shown in (Table 2), 60.6\% study subjects were overweight having Body mass Index between 23.0 to 27.0 and $26 \%$ study subjects were with normal Body mass Index falling between 18.5 to 22.9. Physical activity level was also assessed of all the study participants and as depicted in (Table 3 ), $70.7 \%$ of the participants were having a sedentary life style. A sizable population was following a light and moderate level of physical activity $16.5 \%$ and $10.6 \%$ respectively. Only $1.2 \%$ participants were doing heavy physical exercises by going to gym. Blood groups of all the participants were also enquired and as observed in (Table 4), B +ve was most common (19.7\%) blood group followed by $A+v e(16.5 \%)$ and $O$ +ve (15.7\%). Both $A$-ve and O-ve blood groups constituted $1.6 \%$ each of total whereas B-ve were $0.8 \%$ and none of the participant reported it to be AB-ve. There were $33.1 \%$ participants who were unaware about their blood grouping. Smoking habits were also considered in participants enrolled in the study. Those who never smoked in their life constituted $76.4 \%$ of the total and $23.2 \%$ of study subjects smoked at some point in their life. Alcohol consumption is also considered important as far their health of an individual is considered, there were $37.8 \%$ study subjects who ever consumed alcohol and $61.4 \%$ participants never consumed alcohol. Out of total study subject $40.2 \%$ were vegetarian and $59.8 \%$ were Non-vegetarian. Awareness level of participants regarding preventive strategies for Covid-19 was also assessed. It was observed that $75.2 \%$ participants were aware about the use of mask, social distancing, hand hygiene and cough etiquettes. Further, it was assessed that how many of these participants were practicing all four preventive strategies, it is surprising to know that only $27.8 \%$ were actually practicing it. It was a stressful experience for patients who were Covid positive. Stress experienced by the patients was assessed on likert scale of 1 to 5 . It was observed that only $9.5 \%$ subjects strongly disagreed and $8.7 \%$ disagreed that there was stress with Covid disease. There were $36.2 \%$ strongly agreed and $38.3 \%$ agreed that there was stress with Covid disease whereas $7.3 \%$ said that they can't say about it. Symptomatology of the Covid patients was also enquired, it was observed that $44.1 \%$ patients were asymptomatic and rest of patients were symptomatic. Most common symptoms were Fever, Sore throat, Cough, Dyspnea, Body ache, Malaise, Vomiting, diarrhea, Anosmia. Covid patients were a risk of transmitting infection to their close contacts if proper preventive strategies were not followed.

\section{Discussion}

Majority $(60.6 \%)$ of subjects enrolled were males, this may be due to the reason that males generally work outdoor so chances of transmission is high. Similar results were shown by a study by Kaiyuan Sun (7) et al in which males were affected more as compared to females. Among study participants $40.6 \%$ had completed graduation and $20 \%$ were educated till senior secondary. All the participants were at least educated uptill primary class. MarchMay 2020 were the initial months when disease was transmitted from other parts of worlds to India and mostly through international travel. People residing in urban area could afford to travel abroad, so probability of contracting disease was high among them. It was observed that $60.6 \%$ study subjects were overweight having body mass index ranging from 23.0 to 27.0. In a study by Lighter J et al (11) it was also observed that person with obesity and age less than 60 years are at increased risk of contracting covid disease. In a study by Kwong JC et al(12) it was observed that influenza patients who are obese have more risk of hospitalization due to respiratory illness. In our study around $74.3 \%$ patients were under 
stress which is quite understandable considering limited knowledge about the disease and social stigma attached to the diseased. Similar findings were observed in a study by Bo $\mathrm{H}-\mathrm{X}$ et al (13) where 96.2\% clinically stable covid patients experienced post-traumatic stress. In this study it was found out that $B+$ ve was most common (19.7\%) blood group followed by $A+v e(16.5 \%)$ and least common was $O$ +ve (15.7\%). Similar finding were observed by Michael Zietz (14) et al in a study where they pointed out that "The unadjusted prevalence of initial infection was higher among $A$ and $B$ blood types and lower among $A B$ types, compared with type $O^{\prime \prime}$. We assessed the alcohol consumption by the study subjects and it was observed that $37.2 \%$ subjects consumed alcohol. Alcohol consumption has been reported to increase ACE receptors and Tumor necrosis Factors in the lungs, as studied by Bechara $\mathrm{Rl}$ et al (15) (2003) that it leads to acute lung injury so these it can be pointed out here that these patients were at increased risk of contracting Covid disease. Smoking habits were also considered in participants enrolled in the study and there were $23.2 \%$ of study subjects who ever smoked tobacco. A meta-analysis by Patanavanich $R$ (16) pointed that prevalence of smokers in Covid patients was $6.7 \%$. It is higher in our study; it may be due to the reason that we enquired about ever smoked tobacco which will be high as compared to chronic smokers. It was observed that $44.1 \%$ patients were asymptomatic and rest of patients were symptomatic. Most common symptoms were Fever, Sore throat, Cough, Dyspnea, Body ache, Malaise, Vomiting, diarrhoea, Anosmia. Similar finding was present in a study by Michael C. Grant et al. (17) The most prevalent symptoms in their study were fever $94 \%$, a cough $94 \%$ and fatigue $95 \%$, diarrhea $93 \%$, dyspnea $97 \%$. It was observed that $75.2 \%$ participants knew about the use of mask, social distancing, hand hygiene and cough etiquettes. There is no study in the knowledge of author where awareness has been assessed in covid patients, there are studies where awareness level was assessed in different population groups, in one of the studies by Kaushik $\mathrm{M}$ et al (18) awareness of scientific knowledge was $48 \%$. It is higher in our study it may be due to the reason that it was assessed in covid patients who more sensitized for preventive strategies as they themselves were suffering from Covid. In the same study by Kaushik $\mathrm{M},(18)$ the knowledge of hand wash was $90 \%$, so it can be considered that $48 \%$ awareness is a range for different kinds of preventive strategies.

\section{Conclusion}

It can be concluded by the study that majority of the subjects were males, overweight and blood group A \& B. Knowledge about covid appropriate behavior was adequate among Covid 19 patients as majority were knowing about use of mask, social distancing, hand hygiene and cough etiquettes. Fever, sore throat, cough, dyspnea, bodyache, malaise, vomiting, diarrhoea and anosmia were the major symptoms of Covid patients. About one third of subjects consumed alcohol and around one fourth of subjects smoked tobacco.

\section{Recommendations}

Covid -19 has been the most devastating virus of the century looking to its infectivity and mortality especially in the high-risk population. It can only be controlled through covid appropriate behavior. The study highlights the high-risk groups apart from elderly and persons with co-morbidity. Public health professionals need to focus more upon creating awareness among males, overweight/ obese persons and person with blood group A \& B so that they may be extra cautious and take strict precautions for Covid-19.

\section{Limitation of the study}

A detailed study with large sample size distributed in among both rural and urban populations may be planned to better understand the clinicepidemiological profile of covid patients as the study was planned on the early cases of covid-19.

\section{Relevance of the study}

Though it is widely known that elderly and people with co-morbidities are at higher risk of falling prey to serious form of Covid-19 disease yet many aspects of covid -19 epidemiology were unknown and unexplored. The current study highlights that males, overweight/obese persons and people with blood group A \& B are more prone to contracting Covid-19 disease.

\section{Authors Contribution}

VC, RKY, RV \& MK have designed the study, analyzed the data and have written the manuscript. AN, SG, RD, GA, GK, AS \& VS have interacted with the Covid19 patients, collected and compilation of the data and helped in drafting the article. All the authors 
INDIAN JOURNAL OF COMMUNITY HEALTH / VOL 33 / ISSUE NO 01 / JAN- MAR 2021 have reviewed the manuscript, gave important suggestions for improvement of the article.

\section{Acknowledgement}

Authors would like to thank the Covid patients for sparing their valuable time for participating in the study. We also acknowledge the sincere efforts of district health authorities for providing all the necessary support to investigators for contacting Covid patients.

\section{References}

1. Guan WJ, Ni ZY, Hu Y, Liang WH, Ou CQ, He JX, Liu L, Shan H, Lei $\mathrm{CL}$, Hui DSC, Du B, Li $\sqcup$, Zeng G, Yuen $\mathrm{KY}$, Chen RC, Tang $\mathrm{CL}$, Wang T, Chen PY, Xiang J, Li SY, Wang JL, Liang ZJ, Peng YX, Wei L, Liu Y, Hu YH, Peng P, Wang JM, Liu JY, Chen Z, Li G, Zheng ZJ, Qiu SQ, Luo J, Ye CJ, Zhu SY, Zhong NS; China Medical Treatment Expert Group for Covid-19. Clinical Characteristics of Coronavirus Disease 2019 in China. N Engl J Med. 2020;382(18):1708-1720. doi: 10.1056/NEJMoa2002032. Epub 2020 Feb 28. PMID: 32109013; PMCID: PMC7092819.[PubMed]

2. Chan JF, Kok KH, Zhu Z, Chu H, To KK, Yuan S, Yuen KY. Genomic characterization of the 2019 novel human-pathogenic coronavirus isolated from a patient with atypical pneumonia after visiting Wuhan. Emerg Microbes Infect. 2020;9(1):221236. doi: $10.1080 / 22221751.2020 .1719902$. Erratum in: Emerg Microbes Infect. 2020 Dec;9(1):540. PMID: 31987001; PMCID: PMC7067204.[PubMed].

3. Lu R, Zhao X, Li J, Niu P, Yang B, Wu H, Wang W, Song H, Huang B, Zhu N, Bi Y, Ma X, Zhan F, Wang L, Hu T, Zhou H, Hu Z, Zhou W, Zhao L, Chen J, Meng Y, Wang J, Lin Y, Yuan J, Xie Z, Ma J, Liu WJ, Wang D, Xu W, Holmes EC, Gao GF, Wu G, Chen W, Shi W, Tan W. Genomic characterisation and epidemiology of 2019 novel coronavirus: implications for virus origins and receptor binding. Lancet. 2020;395(10224):565-574. doi: 10.1016/S0140-6736(20)30251-8. Epub 2020 Jan 30. PMID: 32007145; PMCID: PMC7159086.[PubMed]..

4. Zhu N, Zhang D, Wang W, Li X, Yang B, Song J, Zhao X, Huang B, Shi W, Lu R, Niu P, Zhan F, Ma X, Wang D, Xu W, Wu G, Gao GF, Tan W; China Novel Coronavirus Investigating and Research Team. A Novel Coronavirus from Patients with Pneumonia in China, 2019. N Engl J Med. 2020;382(8):727-733. doi: 10.1056/NEJMoa2001017. Epub 2020 Jan 24. PMID: 31978945; PMCID: PMC7092803. [PubMed].

5. Gupta N, Agrawal S, Ish P, Mishra S, Gaind R, Usha G, Singh B, Sen MK, Covid Working Group SH. Clinical and epidemiologic profile of the initial COVID-19 patients at a tertiary care centre in India. Monaldi Arch Chest Dis. 2020;90(1). doi: 10.4081/monaldi.2020.1294. PMID: 32290644.[PubMed]

6. Gupta N, Agrawal S, Ish P, Mishra S, Gaind R, Usha G, Singh B, Sen MK, Covid Working Group SH. Clinical and epidemiologic profile of the initial COVID-19 patients at a tertiary care centre in India. Monaldi Arch Chest Dis. 2020;90(1). doi: 10.4081/monaldi.2020.1294. PMID: 32290644.[PubMed].

7. Sun K, Chen J, Viboud C. Early epidemiological analysis of the coronavirus disease 2019 outbreak based on crowdsourced data: a population-level observational study. Lancet Digit Health. 2020;2(4):e201-e208. doi: 10.1016/S25897500(20)30026-1. Epub 2020 Feb 20. PMID: 32309796; PMCID: PMC7158945.[PubMed]-1
[Clinico-epidemiological profile...] | Chayal V et al

8. Centers for Disease Control and Prevention. How COVID-19 spreads. Available from: https://www.cdc.gov/coronavirus/2019-

ncov/about/transmission.html [Accessed on: 20 Feb 2021]

9. Rothe C, Schunk M, Sothmann P, Bretzel G, Froeschl G, Wallrauch C, Zimmer T, Thiel V, Janke C, Guggemos W, Seilmaier $M$, Drosten C, Vollmar $P$, Zwirglmaier $K$, Zange $S$, Wölfel R, Hoelscher M. Transmission of 2019-nCoV Infection from an Asymptomatic Contact in Germany. N Engl J Med. 2020;382(10):970-971. doi: 10.1056/NEJMc2001468. Epub 2020 Jan 30. PMID: 32003551; PMCID: PMC7120970.[PubMed].

10. Li Q, Guan X, Wu P, Wang X, Zhou L, Tong $Y$, Ren R, Leung KSM, Lau EHY, Wong JY, Xing X, Xiang N, Wu Y, Li C, Chen Q, Li D, Liu $T$, Zhao J, Liu M, Tu W, Chen $C$, Jin L, Yang R, Wang $Q$, Zhou $S$, Wang R, Liu H, Luo Y, Liu Y, Shao G, Li H, Tao Z, Yang Y, Deng Z, Liu B, Ma Z, Zhang Y, Shi G, Lam TTY, Wu JT, Gao GF, Cowling BJ, Yang B, Leung GM, Feng Z. Early Transmission Dynamics in Wuhan, China, of Novel Coronavirus-Infected Pneumonia. N Engl J Med. 2020;382(13):1199-1207. doi: 10.1056/NEJMoa2001316. Epub 2020 Jan 29. PMID: 31995857 ; PMCID: PMC7121484. [PubMed].

11. Lighter J, Phillips $M$, Hochman S, Sterling S, Johnson D, Francois F, Stachel A. Obesity in Patients Younger Than 60 Years Is a Risk Factor for COVID-19 Hospital Admission. Clin Infect Dis. 2020;71(15):896-897. doi: 10.1093/cid/ciaa415. PMID: 32271368; PMCID: PMC7184372.[PubMed];

12. Kwong JC, Campitelli MA, Rosella LC. Obesity and respiratory hospitalizations during influenza seasons in Ontario, Canada: a cohort study. Clin Infect Dis. 2011;53(5):413-21. doi: 10.1093/cid/cir442. PMID: 21844024; PMCID: PMC3156143.[PubMed].

13. Bo HX, Li W, Yang $Y$, Wang $Y$, Zhang $Q$, Cheung $T$, Wu X, Xiang YT. Posttraumatic stress symptoms and attitude toward crisis mental health services among clinically stable patients with COVID-19 in China. Psychol Med. 2020:1-2. doi: 10.1017/S0033291720000999. Epub ahead of print. PMID: 32216863; PMCID: PMC7200846.[PubMed]

14. Zietz M, Zucker J, Tatonetti NP. Associations between blood type and COVID-19 infection, intubation, and death. Nat Commun. 2020;11(1):5761. doi: 10.1038/s41467-020-19623-x. PMID: 33188185; PMCID: PMC7666188.[PubMed]

15. Bechara RI, Brown LA, Eaton DC, Roman J, Guidot DM. Chronic ethanol ingestion increases expression of the angiotensin II type 2 (AT2) receptor and enhances tumor necrosis factoralpha- and angiotensin II-induced cytotoxicity via AT2 signaling in rat alveolar epithelial cells. Alcohol Clin Exp Res. 2003;27(6):1006-14.

10.1097/01.ALC.0000071932.56932.53.

doi: 12824823.[PubMed]

16. Patanavanich R, Glantz SA. Smoking Is Associated With COVID19 Progression: A Meta-analysis. Nicotine Tob Res. 2020;22(9):1653-1656. doi: 10.1093/ntr/ntaa082. PMID: 32399563; PMCID: PMC7239135.[PubMed]

17. Grant MC, Geoghegan L, Arbyn M, Mohammed Z, McGuinness L, Clarke EL, Wade RG. The prevalence of symptoms in 24,410 adults infected by the novel coronavirus (SARS-CoV-2; COVID19): A systematic review and meta-analysis of 148 studies from 9 countries. PLoS One. 2020;15(6):e0234765. doi: 10.1371/journal.pone.0234765. PMID: 32574165; PMCID: PMC7310678.[PubMed]

18. Kaushik M, Agarwal D, Gupta AK. Postgrad Med J Epub ahead of print: [please include Day Month Year]. doi:10.1136/ postgradmedj-2020-138349. 


\section{Tables}

TABLE 1 STUDY SUBJECTS IN FIVE SELECTED DISTRICTS FROM MARCH 2020 TO APRIL 2020

\begin{tabular}{|l|l|l|l|l|}
\hline Name of the district & Covid Cases in March 2020 & Covid Cases in April 2020 & Covid Cases in May 2020 & Total \\
\hline Gurugram & 10 & 47 & 85 & 142 \\
\hline Bhiwani & 0 & 2 & 3 & 5 \\
\hline Jhajjar & 0 & 37 & 74 & 111 \\
\hline Rohtak & 0 & 04 & 80 & 84 \\
\hline Chakhi Dadri & 0 & 0 & 14 & 14 \\
\hline Total & 10 & 90 & 256 & 356 \\
\hline
\end{tabular}

TABLE 2 DISTRIBUTION OF STUDY SUBJECTS AS PER THEIR BODY MASS INDEX (BMI)

\begin{tabular}{|c|c|c|c|}
\hline Sr. No. & BMI & Frequency & Percent \\
\hline 1 & $<18.5$ (underweight) & 20 & 7.9 \\
\hline 2 & $18.5-22.9$ (Normal) & 66 & 26 \\
\hline 3 & $23.0-27.5$ (overweight) & 154 & 60.6 \\
\hline 4 & $>27.5$ (Obese) & 14 & 5.5 \\
\hline 5 & Total & 254 & 100 \\
\hline
\end{tabular}

\section{TABLE 3 DISTRIBUTION OF STUDY SUBJECTS AS PER THEIR PHYSICAL ACTIVITY LEVEL}

\begin{tabular}{|r|l|r|r|}
\hline Sr.no. & Level of physical activity & Frequency & Percent \\
\hline 1 & Sedentary & 182 & 71.7 \\
\hline 2 & Light & 42 & 16.5 \\
\hline 3 & Moderate & 27 & 10.6 \\
\hline 4 & Heavy & 3 & 1.2 \\
\hline 5 & Total & 254 & 100 \\
\hline
\end{tabular}

TABLE 4 DISTRIBUTION OF STUDY SUBJECTS AS PER THEIR BLOOD GROUP TYPES ( $\mathrm{N}=254$ )

\begin{tabular}{|c|c|c|c|}
\hline Sr. No. & Blood Group & Frequency $(n=254)$ & Percentage \\
\hline 1 & At & 42 & 16.5 \\
\hline 2 & B+ & 50 & 19.7 \\
\hline 3 & $\mathrm{O}+$ & 40 & 15.7 \\
\hline 4 & $A B+$ & 28 & 11 \\
\hline 5 & A- & 4 & 1.6 \\
\hline 6 & B- & 2 & 0.8 \\
\hline 7 & O- & 4 & 1.6 \\
\hline 8 & Not Known & 84 & 33.1 \\
\hline & Total & 254 & 100 \\
\hline
\end{tabular}

\section{Figures}

FIGURE 1 DISTRIBUTION OF STUDY SUBJECTS AS THEIR LEVEL OF STRESS ON LIKERT SCALE

घ 1

$\square 2$

$\square 3$

36.2

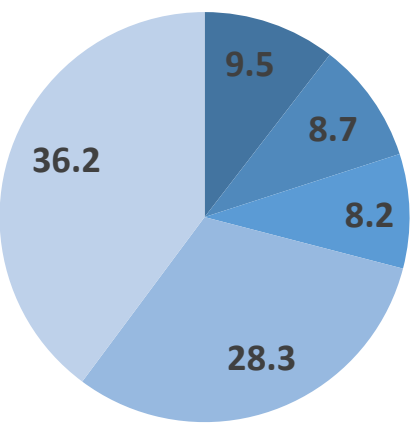

- 4

- 5 